\title{
Altered Properties of Serratia Superoxide Dismutase by Chemical Modification ${ }^{\dagger}$
}

\author{
Kouichi Miyata, Yasushi Nakagawa, Masahira NaKamura, \\ Takashi Ito, Kimiko Sugo, Takeshi Fujita \\ and Katsumi TomoDA \\ Central Research Division, Takeda Chem. Ind. Ltd., \\ Yodogawa-ku, Osaka 532, Japan \\ Received January 25, 1988
}

\begin{abstract}
Serratia Mn-superoxide dismutase (SOD) was modified with dextran (Dx) of M.W. 80K and polyethyleneglycol (PEG) of M.W. 5K. SOD was modified at $34 \%$ of its free amino groups by Dx. DX-SOD retained $67 \%$ of the enzymatic activity of native SOD and had cross-reacted less with anti-SOD in vitro but higher immunogenicity against SOD in vivo. SOD was modified at $24 \%$ of the free amino groups by PEG. PEG-SOD retained $52 \%$ of the enzymatic activity, had lower antigenicity and immunogenicity, and induced immuno-tolerance to SOD. The half-life of PEGSOD in the rat blood circulation was about ten times as long as that of SOD. PEG-modification of SOD enhanced its pharmacological activities as an anti-inflammatory and radioprotective agent.
\end{abstract}

Improvements of enzymatic properties by chemical modification with various polymers including amino acid polymers, ${ }^{1)}$ polysaccharides, ${ }^{2)}$ and chemically synthesized polymers $^{3 \sim 9)}$ have been studied. The impovements were also tried to suppress immunological problems as exogenous enzymes, ${ }^{5)}$ to achieve longer circulation time in the blood, ${ }^{5)}$ to enhance biological activities in vivo, ${ }^{6,7)}$ and to allow enzymatic reactions even in an organic solvent. $^{8,9)}$ We chose Serratia Mn-superoxide dismutase (SOD) ${ }^{10}$ as a model enzyme for modification studies, because SOD scavenges an activated oxgen, superoxide, which causes hazardous biological reactions such as inflammation and cell damage. Dextran (Dx) and polyethylene glycol (PEG) were selected as the modifiers as they were already known to be non-toxic polymers and bovine $\mathrm{Cu}, \mathrm{Zn}$-superoxide dismutase was conjugated with the polymers. $^{6 \sim 9)}$

Serratia SOD retained a high percentage of its enzymatic activity after Dx- and PEGmodifications. The purpose of this study was to prepare modified SOD with improved properties, decreasing immunological problems, increasing lifetime in the blood, and enhancing biological activity in vivo.

\section{MATERIALS AND METHODS}

SOD and modification. SOD was purified by the method described previously ${ }^{10)}$ and SOD activity was assayed by the method of Ishiguro et al. ${ }^{11)}$ SOD was modified with dextran (M.W. about $80 \mathrm{~K}$ ) using $\mathrm{BrCN},{ }^{12)}$ and with monomethoxypolyethyleneglycol (PEG) (M.W. 5K) using trichlorotriazine as an adduct reagent of double $\mathrm{PEG}$ chains by the method of Matsushima et al. ${ }^{13)}$ The modifications were done using excess dextran or PEG at $4^{\circ} \mathrm{C}$ and $\mathrm{pH} 9.0$ for $2 \mathrm{hr}$ to prevent inactivation of SOD.

The free amino groups of the modified SOD preparations were measured using trinitrobenzenesulfonate by the method of Habeeb. ${ }^{143}$

Immunological experiments. The antigenicity of the SOD preparations was detected by the double diffusion method

$\dagger$ Presented at the Annual Meeting of the Agricultural Chemical Society of Japan; Tokyo, April 4, 1987.

Abbreviations: SOD, Serratia Mn-superoxide dismutase; Dx, dextran; Dx-SOD, Dx-modified SOD; PEG, monomethoxy-polyethyleneglycol; PEG-SOD, PEG-modified SOD; FCA, Freund's complete adjuvant; OA, ovalbumin; PCA, passive cutaneous anaphylaxis. 
of Ouchterlony ${ }^{15)}$ using anti-SOD prepared in rabbits. ${ }^{16)}$ The immunogenicity of the native or modified SOD was evaluated by measuring anti-SOD production in mice after immunization. Mice $(\mathrm{A} / \mathrm{J}$, male, $N=8)$ received an intraperitoneal injection of the preparation $(20 \mu \mathrm{g}$ as SOD) emulsified with Freund's complete adjuvant (FCA). The mice were bled from the orbital sinus, 7 and 14 days after the injection. Anti-SOD (IgE) in the plasma was assayed by the rat $4 \mathrm{hr}$ passive cutaneous anaphylactic (PCA) reaction ${ }^{17)}$ and $\mathrm{PCA}$ titers were expressed as the reciprocal of the weakest serum dilution with a positive reaction.

Immunotorelogenic activity induced by the modified SOD preparations was assessed in mice (A/J , male, $N=8$ ) by intravenous injection of the modified enzymes ( $20 \mu \mathrm{g}$ as SOD) 7 days before a challenge with SOD. SOD $(20 \mu \mathrm{g})$ emulsified with FCA was administered intraperitoneally on days 0,14 , and 28 . Anti-SOD $(\operatorname{IgE})$ was assayed by the PCA method described above. ${ }^{17)}$

Half-life. The in vivo half-life of the modified SOD preparations was measured in rats ( $\mathrm{SD}$, male, $N=5$ ). The rats were given the modified enzymes ( $5 \mathrm{mg} / \mathrm{kg}$ as SOD) by intravenous injection. Blood samples were taken from the tail vein at prescribed intervals and the level of SOD in the plasma was assayed as above ${ }^{12)}$ with $3 \mathrm{~mm} \mathrm{NaCN}$ to inactivate $\mathrm{Cu}, \mathrm{Zn}$-SOD of the host rats.

Pharmacological experiments. Anti-inflammatory activities were evaluated by carrageenin induced abscess ${ }^{18}$ ) and Masugi's nephritis ${ }^{19)}$ in rats (SD, male), and passive reversed Arthus reaction ${ }^{20}$ and delayed type hypersensitivity ${ }^{21)}$ in mice (A/J, male). SOD derivatives and other materials were dissolved in and diluted with saline.

In the carrageenin abscess test, the SOD preparations were administered intravenously to rats $(N=6) 30 \mathrm{~min}$ before the subcutaneous injection of $0.5 \mathrm{ml}$ of $2 \%$ carrangeenin into the dorsal sacral region. The abscess (exudate) weight was measured $24 \mathrm{hr}$ after the injection of the carrangeenin and the inhibitory activity of the SOD against the abscess formation was calculated by comparison with that of the control (saline). ${ }^{18 \text { 3 }}$

A passive reversed Arthus reaction in mice $(N=10)$ was evoked by injection of $10 \mu \mathrm{l}$ of rabbit anti-ovalbumin (antiOA) serum into the left hind footpad and intraperitoneal injection of $\mathrm{OA}(1 \mathrm{mg})$ in $0.2 \mathrm{ml}$ saline. Into the right hind footpad, $10 \mu \mathrm{l}$ of normal rabbit serum was injected as a control. PEG-SOD was given by intravenous injection $60 \mathrm{~min}$ after the antigen challenge. The thickness of both footpads was measured $120 \mathrm{~min}$ after the challenge with a dial thickness gauge (Peacock). The footpad swelling reaction was evaluated by measuring the difference between the thickness of the left and right footpads. The anti-OA was prepared in rabbits by repetitive intraperitoneal immunization with OA emulsified with $\mathrm{FCA}^{20)}$

Delayed type hypersensitivity was induced by injection of OA $(25 \mu \mathrm{g})$ in $25 \mu$ l of saline into the left hind footpad and $25 \mu \mathrm{l}$ of saline into the right hind footpad of mice
$(N=6)$ which had been immunized by subcutaneous injection of an emulsion of OA $(300 \mu \mathrm{g})$ with FCA, 2 weeks before. PEG-SOD was administered intravenously $30 \mathrm{~min}$ before the injection of $\mathrm{OA}^{21)}$ and the thickness of both footpads was measured $24 \mathrm{hr}$ after the administration of OA. The results were evaluated as in the passive reversed Arthus reaction.

In rats with Masugi's nephritis, ${ }^{19)}$ PEG-SOD was administered intravenously every day at $5 \mathrm{mg} / \mathrm{kg} /$ day to rats $(N=5)$ from 3 days before, to 21 days after the intravenous injection of anti-glomerulobasement membrane (GBM). Urine from the rats was pooled over $24 \mathrm{hr}$ and the urinary protein was measured by the method of Lowry. ${ }^{22}$ Anti-GBM was prepared in rabbits by repetitive intraperitoneal immunization of rat GBM emulsified with FCA at 2 week intervals.

Radioprotective activity was measured in mice $(N=$ 18). ${ }^{23)}$ SOD preparations were injected intravenously at $40 \mathrm{mg} / \mathrm{kg}, 48,24$, and $1 \mathrm{hr}$ before irradiation with ${ }^{60} \mathrm{Co}$ at $729 \mathrm{rem} /$ mouse and the mortality of the mice over 2 weeks after the irradiation was observed.

Materials. PEGs and trichlorotriazine were made by Aldrich Chem. Co. and other reagents were purchased from Wako Pure Chem. Ind.

\section{RESULTS}

Modified amino groups and retention of enzymatic activity of DX-SOD and PEG-SOD Dx-SOD and PEG-SOD had $34 \%$ and $24 \%$ of the free amino groups of the native SOD modified, and retained $67 \%$ and $52 \%$ of the original enzymatic activity, respectively.

\section{Immunological studies}

a. Antigenicity of Dx-SOD and PEG-SOD. Cross-reactivity of the modified SOD with anti-SOD was tested on immunodiffusion plates. Immunoprecipitation was only observed with amounts of Dx-SOD and PEGSOD protein 50 and 10 times, respectively, greater than that of native SOD required for the precipitation, indicating that the antigenic sites of the SOD were sterically masked by the Dx- and PEG-modifications.

b. Immunogenicity and tolerogenicity of Dx-SOD and PEG-SOD. Antisera from mice immunized with Dx-SOD had higher PCAtiters than those with native SOD 14 days after the immunization (Table I) and also reacted strongly with Dx-SOD (data not shown). 


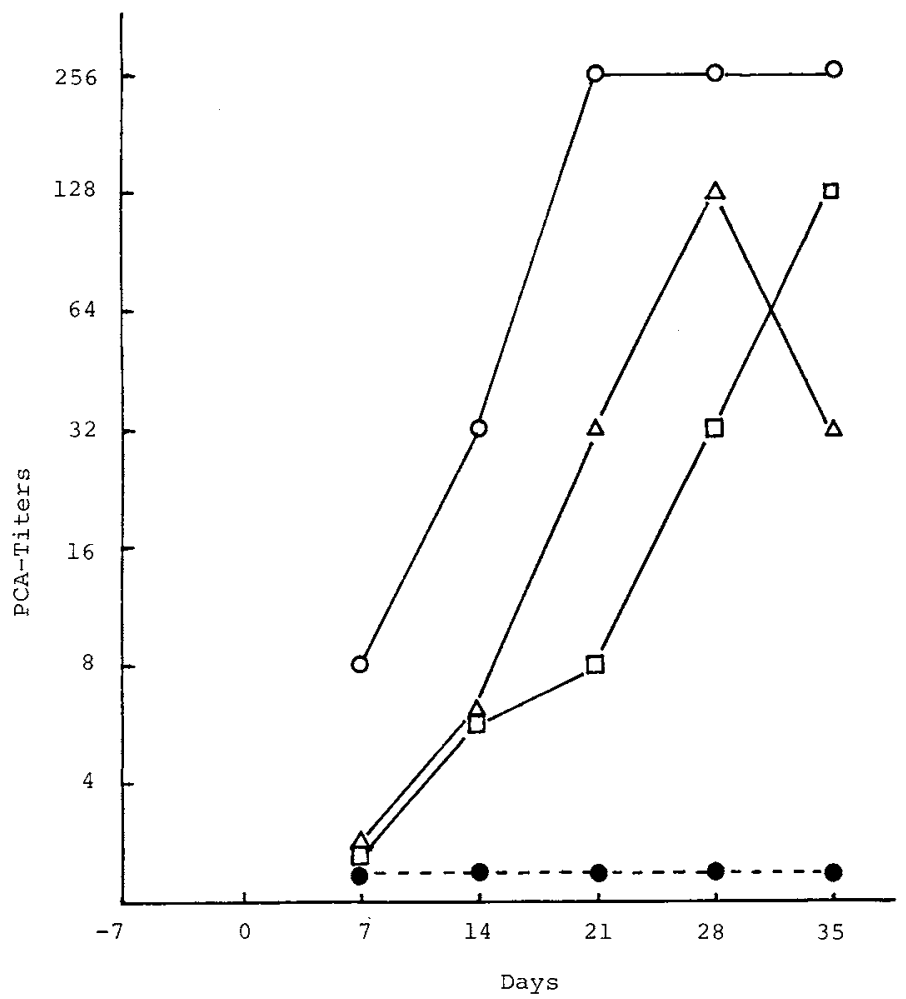

FIG. 1. Immunotolerance Induced by PEG-SOD in Mice.

Saline $-\mathrm{O}-$, Dx-SOD $-\triangle-$, SOD $-\square-$, or PEG-SOD - - (20 $\mu \mathrm{g}$ as SOD) was administered i.v. 7 days before immunization with SOD of mice $(N=8)$. SOD $(20 \mu \mathrm{g})$ emulsified with FCA was administered i.p. on days 0,14 , and 28 . The anti-SOD level in the plasma was measured by the PCA method.

However, antisera from mice immunized with PEG-SOD did not react detectably with SOD (Table I) and PEG-SOD (data not shown).

These results indicate that Dx-SOD was more immunogenic than SOD, but that PEGSOD did not stimulate antibody production. This was confirmed by the induction of immunotolerance with PEG-SOD as shown in Fig. 1.

From the above results, PEG-SOD was selected for further investigation.

c. Modification of SOD with PEG of various molecular weights. SOD was modified with PEG of various molecular weights by the method described in Methods. The percentage of modified amino groups and the remaining enzymatic activities of the PEG-SOD preparations are shown in Table II.

d. Immunogenicity of PEG-SOD preparations. The immunogenicity of the PEG-SOD
TABle I. ImMUNOGENICITy OF SOD, Dx-SOD AND PEG-SOD

\begin{tabular}{|c|c|c|}
\hline \multirow{2}{*}{ Immunogen } & \multicolumn{2}{|c|}{ PCA titers on day } \\
\hline & 7 & 14 \\
\hline SOD & 8 & 32 \\
\hline Dx-SOD & $<4$ & 256 \\
\hline PEG-SOD & $<4$ & $<4$ \\
\hline
\end{tabular}

SOD preparations ( $20 \mu \mathrm{g}$ as SOD) emulsified with FCA were administered i.p. and antibodies to SOD were measured on days 7 and 14 by the PCA method described in METHODS. The maximum concentration of antisera used was a 4 times dilution of the original sera.

preparations was measured as described above. As shown in Table III, the production of antibody to SOD was sharply decreased by increasing the molecular weight of PEG. Administration of PEG (1900 and 5000)*-SODs 
did not induced many antibodies against SOD (Table III) and PEG (5000)-SOD (data not shown).

TABle II. SOD Modified with PEG of Various MOLECUlar Weights

\begin{tabular}{lllll}
\hline & \multicolumn{4}{c}{ M.W. of PEG } \\
\cline { 2 - 5 } & 350 & 750 & 1900 & 5000 \\
\hline $\begin{array}{l}\text { Modified amino group } \\
\text { SOD activity }\end{array}$ & $48 \%$ & $48 \%$ & $48 \%$ & $25 \%$ \\
\hline
\end{tabular}

SOD was modified with PEG of various M.W.s as described in METHODS.

TABLE III. IMMUnOGENICITy OF SOD AND PEG-SODs

\begin{tabular}{|c|c|c|c|}
\hline \multirow{2}{*}{ Immunogen } & \multicolumn{3}{|c|}{ PCA titers on day } \\
\hline & 7 & 14 & 28 \\
\hline SOD & 4 & 64 & 512 \\
\hline PEG(350)-SOD & $<4$ & 8 & 256 \\
\hline PEG(750)-SOD & $<4$ & 4 & 32 \\
\hline PEG(1900)-SOD & $<4$ & $<4$ & $<4$ \\
\hline PEG(5000)-SOD & $<4$ & $<4$ & $<4$ \\
\hline
\end{tabular}

SOD preparations ( $20 \mu \mathrm{g}$ as SOD) emulsified with FCA were administered i.p. to mice on days 0 and 14 , and antibodies against SOD were assayed by the PCA method on days 7,14 , and 28 .
Clearance rates of $P E G-S O D$ s in the blood

The half-life of PEG-SOD preparations was estimated by assaying the enzymatic activity in the plasma obtained at prescribed intervals after i.v. injection to rats at $5 \mathrm{mg}$ as $\mathrm{SOD} / \mathrm{kg}$. As shown in Fig. 2, the half-life of PEG-SOD preparations increased with the increase in the molecular weight of PEG.

The half-life of native SOD and PEG(5000)SOD were $1.6 \pm 0.04 \mathrm{hr}$ and $17.5 \pm 3.5 \mathrm{hr}$ at $1 \mathrm{mg} / \mathrm{kg}$, respectively, indicating similar result at $5 \mathrm{mg} / \mathrm{kg}$ in Fig. 2. Thus, the half-life of PEG(5000)-SOD was about ten times as long as that of native SOD.

From the above results, PEG(5000)-SOD was selected as the most suitable modified enzyme for further study.

\section{Pharmacological activities of PEG-SOD}

Various pharmacological activities of PEG(5000)-SOD were assessed and compared with native SOD. SOD and PEG-SOD were administered by $i . v$. injection in all of the experiments.

a. Anti-inflammatory activities. Table IV shows the inhibitory activity of PEG-SOD against the abscess formation induced by carrageenin. PEG-SOD inhibited the abscess

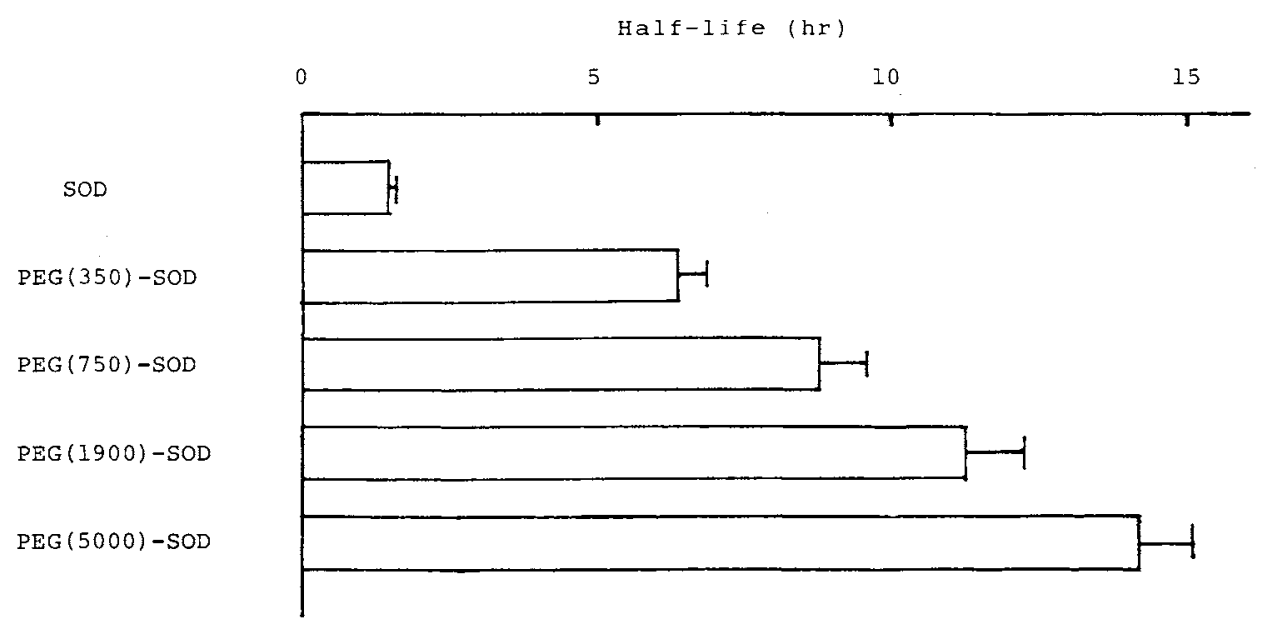

FIG. 2. Plasma Clearance Rates of SOD and PEG-SODs in Rats.

SOD preparations $(5 \mathrm{mg}$ as $\mathrm{SOD} / \mathrm{kg}$ ) were administered $i . v$. to rats $(N=5)$, the SOD activity in the plasma was assayed and half-life time was calculated (mean + S.D.).

\footnotetext{
* The number in parenthesis represents the mean molecular weight of PEG used for the modification of SOD.
} 
formation dose-dependently and the inhibition was statistically significant at all doses given. The inhibitory activity of SOD at $2 \mathrm{mg} / \mathrm{kg}$ was less than that of PEG-SOD at $0.5 \mathrm{mg} / \mathrm{kg}$.

PEG-SOD was significantly effective at $0.5 \mathrm{mg} / \mathrm{kg}$ in the mouse passive reversed Arthus reaction (Table V); Native SOD had nearly the same activity only at $2 \mathrm{mg} / \mathrm{kg}$.

Table IV. Anti-Inflammatory Activity of PEGSOD AGAINST CARRAGEENIN-INDUCED ABSCESSES IN RATS

\begin{tabular}{lcccc}
\hline & $\begin{array}{c}\text { Dose }^{a} \\
(\mathrm{mg} / \mathrm{kg})\end{array}$ & $N$ & \multicolumn{1}{c}{$\begin{array}{c}\text { Abscess weight } \\
(\mathrm{g})\end{array}$} & $\begin{array}{c}\text { Inhibition } \\
(\%)\end{array}$ \\
\hline Control & - & 6 & $1.575 \pm 0.028$ & - \\
PEG-SOD & 0.5 & 6 & $1.309 \pm 0.063^{* *}$ & 16.9 \\
& 1.0 & 6 & $1.269 \pm 0.086^{* *}$ & 19.4 \\
& 2.0 & 6 & $1.176 \pm 0.092^{* *}$ & 25.3 \\
& 4.0 & 6 & $1.104 \pm 0.087^{* * *}$ & 29.9 \\
\hline
\end{tabular}

PEG-SOD was administered i.v. $30 \mathrm{~min}$ before the injection of carrageenin. The abscess was excised $24 \mathrm{hr}$ after the carrageenin injection and was weighed.

a As SOD.

b Mean \pm S.E. $* * p<0.01 .{ }^{* * *} p<0.001$.
PEG-SOD induced significant inhibition at $1.6 \mathrm{mg} / \mathrm{kg}$ in the mouse delayed type hypersensitivity test (Table VI), but SOD was inefficacious even at $8 \mathrm{mg} / \mathrm{kg}$.

In rats with Masugi's nephritis, urinary protein is increased by an allergy caused by the

Table V. Effects of PEG-SOd on the Passive Reversed Arthus Reaction in Mice

\begin{tabular}{lcclc}
\hline & $\begin{array}{c}\text { Dose } \\
(\mathrm{mg} / \mathrm{kg})\end{array}$ & $N$ & $\begin{array}{c}\text { Paw-swelling } \\
\text { Mean } \pm \text { S.D. } \\
\left(\times 10^{-2} \mathrm{~mm}\right)\end{array}$ & $\begin{array}{c}\text { Inhibition } \\
(\%)\end{array}$ \\
\hline Saline & - & 10 & $37.3 \pm 7.4$ & - \\
PEG-SOD & 0.25 & 10 & $36.2 \pm 12.1$ & 2.9 \\
& 0.50 & 10 & $26.3 \pm 14.0^{*}$ & 29.5 \\
& 1.0 & 10 & $19.1 \pm 5.9^{* * *}$ & 48.8 \\
& 4.0 & 10 & $15.0 \pm 6.8^{* * *}$ & 59.8 \\
\hline
\end{tabular}

Anti-ovalbumin $(10 \mu \mathrm{l})$ was injected into the footpad of mice and ovalbumin ( $1 \mathrm{mg})$ was administered i.v. PEGSOD was given $i . v .60 \mathrm{~min}$ after the ovalbumin injection and the footpad swelling was measured $60 \mathrm{~min}$ after the injection of PEG-SOD.

a As SOD.

$* p<0.05$. *** $p<0.001$.

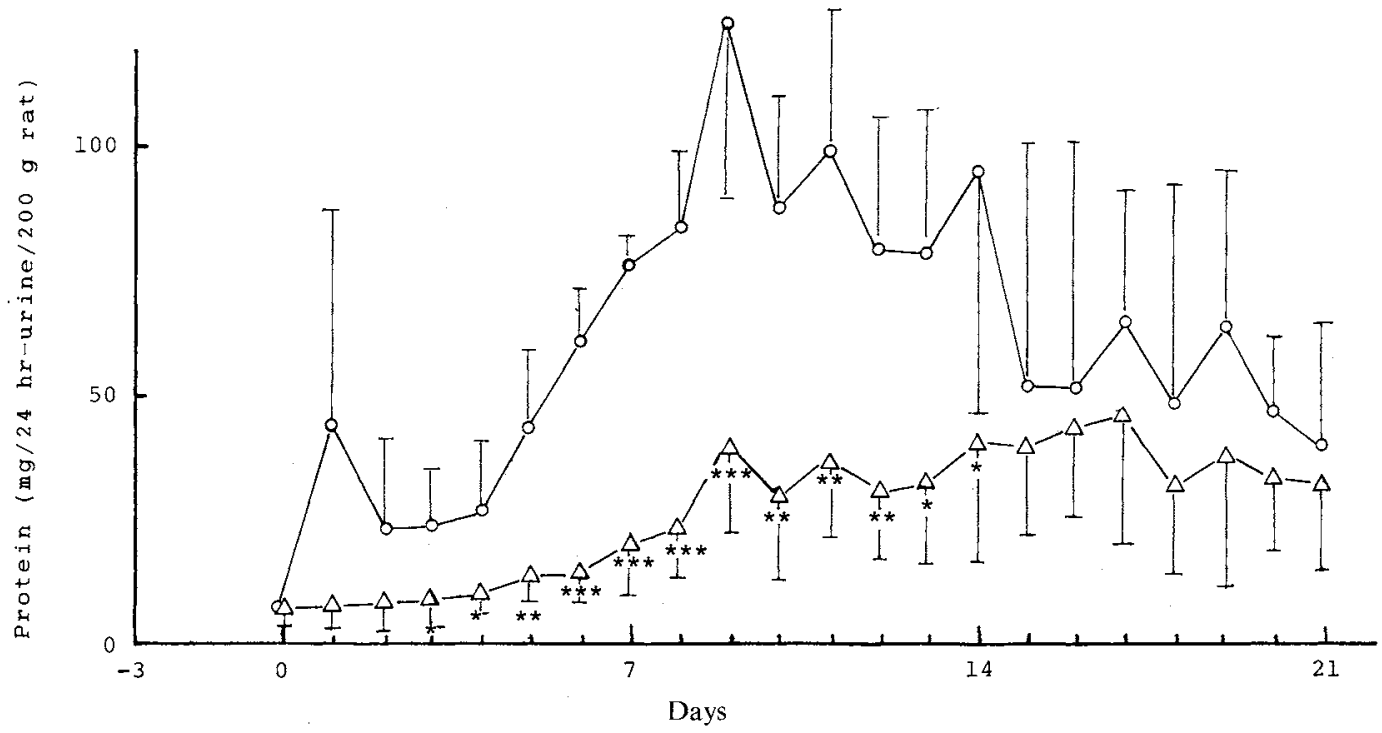

FIG. 3. Effects of PEG-SOD on Urinary Protein in Rats with Masugi's Nephritis.

PEG-SOD $-\triangle$ - or saline $-O$ - was administered $i . \psi$ to rats $(N=5)$ every day at $5 \mathrm{mg}$ as $\mathrm{SOD} / \mathrm{kg} / \mathrm{day}$ from 3 days before $i . v$. injection of anti-rat glomerulobasement membrane. Urine from rats with an immunecomplex disease (Masugi's nephritis) was pooled for $24 \mathrm{hr}$ and the urinary protein was measured by the method of Lowry. Protein was corrected as the mean $\mathrm{mg} / 24 \mathrm{hr}-\mathrm{urine} / 200 \mathrm{~g}$ weight of rat. Urinary protein from normal rats was below $20 \mathrm{mg} / 24 \mathrm{hr}$-urine $/ 200 \mathrm{~g}$ rat.

Mean +or-S.D. $\quad * p<0.05 . \quad * * p<0.01 . \quad * * * p<0.001$. 
Table VI. Effects of PEG-SOD on Delayed Type HyPeRSENSITIVITY IN MiCE

\begin{tabular}{lcccc} 
& $\begin{array}{c}\text { Dose } \\
(\mathrm{mg} / \mathrm{kg})\end{array}$ & $N$ & $\begin{array}{c}\text { Swelling } \\
\text { Mean } \pm \text { S.D. } \\
\left(\times 10^{-2} \mathrm{~mm}\right)\end{array}$ & $\begin{array}{c}\text { Inhibition } \\
(\%)\end{array}$ \\
\hline Saline & - & 6 & $23.2 \pm 6.8$ & - \\
PEG-SOD & 1.6 & 6 & $15.3 \pm 4.1^{*}$ & 34.1 \\
& 8.0 & 6 & $9.0 \pm 4.2^{* *}$ & 61.2 \\
\hline
\end{tabular}

Ovalbumin $(0.3 \mathrm{mg})$ emulsified with FCA was injected s.c. to mice 2 weeks before $i . v$. injection of PEG-SOD. Ovalbumin $(25 \mu \mathrm{g})$ was injected into the footpad $30 \mathrm{~min}$ after the PEG-SOD injection and the footpad swelling was measured $24 \mathrm{hr}$ after the challenge.

a As SOD

* $p<0.05$. ** $p<0.01$.

TABLE VII. RADIOPROTECTION BY SOD AND PEG-SOD in Mice IRRadiated By $\gamma$-Rays

\begin{tabular}{lrr} 
& $N$ & Mortality \\
\hline Saline & 18 & $15 / 18$ \\
SOD & 18 & $10 / 18$ \\
PEG-SOD & 18 & $1 / 18$ \\
\hline
\end{tabular}

Mice were given SOD or PEG-SOD i.v. at $40 \mathrm{mg}$ as $\mathrm{SOD} / \mathrm{kg} /$ day for 3 days and subsequently irradiated with ${ }^{60} \mathrm{Co}$ at $729 \mathrm{rem} / \mathrm{mouse}$. The mortality of the mice was measured for 2 weeks after the irradiation.

formation of an immune complex. Urinary protein was reduced significantly by daily administration of PEG-SOD at $5 \mathrm{mg} / \mathrm{kg} /$ day (Fig. 3) but only slightly reduced by the same amount of SOD (data not shown).

b. Radioprotection. The protective effect of PEG-SOD and SOD against $\gamma$-radiation injury in mice was evaluated after administration at $40 \mathrm{mg} / \mathrm{kg} /$ day for 3 days before irradiation. The mortality of the mice was calculated during 14 days after irradiation. The mortality of the mice treated with PEG-SOD was significantly lower and that of the mice treated with SOD was moderately lower than that of the control mice (Table VII).

\section{DISCUSSION}

DX-SOD and PEG-SOD had longer halflives and greater anti-inflammatory activities than native SOD (data for Dx-SOD not shown). Dx-SOD was more immunogenic than the native enzyme, but PEG-SOD did not elicit the production of antibodies to both SOD and PEG-SOD, and induced immunotolerance to both enzymes. Therefore, PEG-modification of the enzyme might be useful to reduce immunological problems, and Dx-modification could be suitable to produce a vaccine.

PEG-modifications of bovine $\mathrm{Cu}, \mathrm{Zn}$ SOD,$^{24.25)}$ proteins, ${ }^{26.27)}$ and enzymes ${ }^{8.9)}$ have been reported to be useful due to increases in the circulation time and decreases in immunogenicity. The enhancement of pharmacological activities by PEG-modification has been reported for other SODs.6.7.24.25.28) It was generally maintained that the enhancement was related only to longer circulation in the blood. The reasons, however, are presumed to be as follows:

First, the increase in half-life allows the maintenance of its scavenging activity against superoxide for longer periods in the blood. SOD may prevent the formation of clastogenic and chemotactic factors by superoxide in the blood (systemic effect). ${ }^{28}$ ) The second reason is improvement of the binding affinity of SOD for cell membranes (local effect). According to Michelson et al., ${ }^{29)}$ the anti-inflammatory activity of SOD is not a function of molecular weight or half-life time in the circulation but of its binding affinity for the cell membranes, especially at the site of local inflammation. Various SODs of different types and sources showed large differences in anti-inflammatroy activities. For example, among 18 different SODs, Mn-SOD from Escherichia coli was most effective but human Mn-SOD was ineffective in a rat carrageenan model. ${ }^{29}$ Therefore, it is suggested that the structure and properties of the individual SOD are more important than its enzymatic activity to evaluate the biological activities.

PEG has both hydrophilic and hydrophobic properties so that PEG-enzymes may be enzymatically active in both aqueous and lipophilic environments and could interact with cell membranes owing to the amphipathic 
properties.

As PEG-SOD is thought to have improved binding affinity for cell membranes, the distribution of the PEG-SOD in vivo after the injection should be investigated in more detail to elucidate the enhancement of its pharmacological activities.

Acknowledgments. We are grateful to Dr. S. Kuzuna for the evaluation of PEG-SOD by the carrageenin abscess method and to Drs. K. Morita, Y. Sugino and M. Nishikawa of the Takeda Laboratories for their encouragement.

\section{REFERENCES}

1) F.-T. Liu, M. Zinnecker, T. Hamaoka and D. H. Katz, Biochemistry, 18, 690 (1979).

2) M. Usui and T. Matsuhashi, J. Immunol., 122, 1266 (1979).

3) H. F. Hixson, Biotech. Bioeng., 15, 1012 (1973).

4) B.-U. von Specht, H. Seinfeld and W. Brendel, Hoppe Seyler's Z. Physiol. Chem., 354, 1659 (1973).

5) A. Abuchowski, T. Van Es, N. C. Palczuk and F. F. Davis, J. Biol. Chem., 252, 3578 (1977).

6) P. S. Pyatak, A. Abuchowski and F. F. Davis, Res. Commun. Chem. Pathol. Pharmacol., 29, 113 (1980)

7) J. M. McCord, and K. Wong, "Oxygen free radicals and tissue damage," Ciba Foundation 65, Excerpta Medica, New York, 1979, pp. 343 351 .

8) A. Futami and Y. Inada, Kagaku, 40,650 (1985).

9) Y. Inada, T. Yoshimoto, A. Matsushima and Y. Saito, Trends Biotech., 4, 68 (1986).

10) K. Maejima, K. Miyata and K. Tomoda, Agric. Biol. Chem., 47, 1537 (1983).

11) I. Ishiguro, R. Shinohara, A. Ishikura and J. Naitou, Chem. Pharm. Bull., 22, 2935 (1974).

12) J. Porath and R. Axen, "Methods in Enzymology,"
Vol. 44, ed. by K. Mosbach, Academic Press, New York, 1976, pp. 19 45.

13) A. Matsushima, H. Nishimura, Y. Ashihara, Y. Yokota and Y. Inada, Chem. Lett., 1980, 773.

14) A. F. S. A. Habeeb, Anal. Biochem., 14, 328 (1966).

15) O. Ouchterlony, Progr. Allergy, 5, 1 (1958).

16) M. Nakamura, K. Maejima, K. Miyata and K. Tomoda, Agric. Biol. Chem., 51, 47 (1987).

17) J. S. Garvey, N. E. Cremer and D. H. Sussdorf, "Methods in Immunology," 3rd Ed., W. A. Benjamin Inc., London, 1977, pp. 455 458.

18) S. Tamura and S. Kuzuna, Folia Pharmacol. Japon, 84, 337 (1984).

19) Y. Suzuki, M. Itoh and T. Nagamatsu, Japan $J$. Pharmacol., 28, 197 (1978).

20) J. W. Lens, W. B. Van den Berg, L. B. A. Van de Putte, J. H. M. Borden and S. P. M. Lems, Clin. Exp. Immunol, 57, 520 (1984).

21) O. Shio, Y. Nakagawa and H. Kawaji, J. Antibiot., 34, 452 (1981).

22) O. H. Lowry, N. J. Rosebrough, A. L. Farr and R. J. Randali, J. Biol. Chem., 193, 265 (1951).

23) A. Petkau, W. S. Chelack, S. D. Pleskach, B. E. Meeker and C. M. Brady, Biochem. Biophys. Res. Commun., 65, 886 (1975).

24) C. O. Beauchamp, S. L. Gonias, D. P. Menapace and S. U. Pizzo, Anal. Biochem., 131, 25 (1983).

25) F. M. Veronese, E. Boccu, O. Schiavon, G. P. Velo, A. Conforti, L. Franco and R. Milanino, J. Pharm. Pharmacol., 35, 757 (1983).

26) W. Y. Lee and A. H. Sehon, Nature, 267, 618 (1977).

27) T. P. King and C. Weiner, Int. J. Peptide Protein Res., 16, 147 (1980).

28) J. M. McCord, K. Wong, S. H. Stokes, W. F. Petrone and D. English, "Pathology of Oxygen," ed. by A. P. Autor, Academic Press, New York, 1982, pp. $75 \sim 81$.

29) A. M. Michelson, G. Jadot and K. Puget, "Biological Role of Reactive Oxygen Species in Skin," ed. by $O$. Hayaishi, S. Imamura and Y. Miyachi, University of Tokyo Press, Tokyo, 1987, pp. $199 \sim 210$. 